\title{
EFFECT OF BIOCHAR ON CADMIUM, NICKEL AND LEAD UPTAKE AND TRANSLOCATION IN MAIZE IRRIGATED WITH HEAVY METAL CONTAMINATED WATER
}

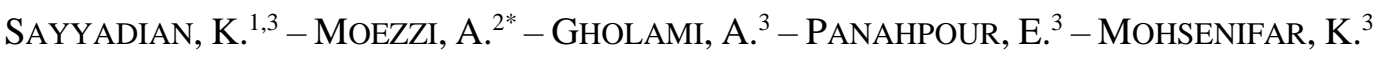 \\ ${ }^{I}$ Department of Soil Science, Khouzestan Science and Research Branch, Islamic Azad \\ University, Ahvaz, Iran \\ ${ }^{2}$ Department of Soil Science, Chamran University, Ahvaz, Iran \\ ${ }^{3}$ Department of Soil Science, Ahvaz Branch, Islamic Azad University, Ahvaz, Iran \\ *Corresponding author \\ e-mail: abdulamirmoezzi@yahoo.com
}

(Received 25 $5^{\text {th }}$ Jul 2018; accepted $7^{\text {th }}$ Nov 2018)

\begin{abstract}
This study was conducted to investigate the effect of biochar on bioavailability reduction of cadmium $\left(\mathrm{Cd}^{+2}\right)$, nickel $\left(\mathrm{Ni}^{+2}\right)$, and lead $\left(\mathrm{Pb}^{+2}\right)$ and its subsequent effects on soil properties and maize plant growth in a soil which was irrigated by contaminated water with above heavy metals. Twelve different biochar were prepared under two temperatures of $500{ }^{\circ} \mathrm{C}$ and $700{ }^{\circ} \mathrm{C}$ by using six biomass including residuals of wheat (WB), chickpea (CB), maize (MB), reed (RB), olive (OB) and sugarbeet (SB). Physicochemical properties of biochar including product percentage, percentage volatile matter, ash, $\mathrm{pH}$, electrical conductivity (EC), cation exchange capacity (CEC), specific surface, and organic carbon (OC) were studied as well. Subsequently, the effects of 3 biochar selected under $700{ }^{\circ} \mathrm{C}\left(\mathrm{MB}_{700}\right.$, $\mathrm{RB}_{700}, \mathrm{WB}_{700}$ ) at the levels of $0 \%, 2 \%$, and $4 \%$ were employed for pot experiments. The results showed that higher level of temperature significantly $(\mathrm{P}<0.05)$ increased $\mathrm{pH}, \mathrm{EC}$, ash percentage, specific surface area, and OC content of soil however $\mathrm{Cd}, \mathrm{Ni}$, and both shoot and root dry biomass decreased. This study results indicated that high application of biochar significantly decreased leaf area, and also shoot and root biomass.
\end{abstract}

Keywords: maize, contaminated water, volatile matter, heavy metal, biochar

\section{Introduction}

Soils are increasingly become contaminated by accumulation of heavy metals through applying urban and industrial sewage sludge along with chemical fertilizers (Hejazizadeh et al., 2016). In developing countries due to expanding of population, food demand is driving up which in turn increases the resources application and subsequently resulted in rising accumulation of $\mathrm{Cd}, \mathrm{Ni}$, and $\mathrm{Pb}$ in soils. Long term application of sewage sludge even with low concentration of heavy metals can also result in accumulation of these metals in soils (Lu et al., 2015). Low availability of water due to population increment, climate change and climate pollution has been turned into one of the major environment problems (Yao et al., 2012). Accumulation of heavy metal in soils is not only a serious threat for plants but also is a potential danger to human health as well (Hejazizadeh et al., 2016). Heavy metal should be of more concern as in contrast to organic matters, they do not decompose (Ingole and Tale, 2016).

In recent decade, biochar has gained more attention as their capability of carbon sequestration mitigates global warming, enhances soil fertility and reduces both organic and inorganic pollutants of soil (Zheng et al., 2013). Biochar is a carbonaceous material product of organic waste under oxygen-limited or fully depleted oxygen condition 
(Zhao et al., 2017; Lehmann, 2007). Physicochemical properties of biochar depend on starting material and applied temperature and by increasing temperature beyond $550{ }^{\circ} \mathrm{C}$, specific surface area and aromatic components of biochar would increase (Elzobair, 2013). Biochar can also reduce the pollutants movement and thus prevent their uptake by crops (Yao et al., 2012). Different characters of biochar (due to feedstock or pyrolysis conditions) can enforce different impacts on soils fertility and crop production (Paneque et al., 2016). Various studies have indicated that biochar positive effects on environment and for crop production it depends on biochar feedstock and its production conditions (da Silva et al., 2017). Most of published results are originated from tropical, subtropical, and temperate regions but the impact of biochar in Mediterranean regions with hot and dry summers containing calcareous soils has not been fully realized yet (Paneque et al., 2016).

This study was conducted to investigate the effect of biochar on bioavailability reduction of cadmium $\left(\mathrm{Cd}^{+2}\right)$, nickel $\left(\mathrm{Ni}^{+2}\right)$, and lead $\left(\mathrm{Pb}^{+2}\right)$ and its subsequent effects on soil characteristics and corn plant growth in a soil which was irrigated by contaminated water with above heavy metals.

\section{Materials and methods}

This experiment was conducted as factorial based on complete random design with three replications in Anahita soil-plant-water analysis lab of Kermanshah state (Iran) in 2017. Twelve different biochars were prepared under two temperatures of $500{ }^{\circ} \mathrm{C}$ and $700{ }^{\circ} \mathrm{C}$ by using six starting biomass including residuals of wheat $\left(\mathrm{WB}_{500}, \mathrm{WB}_{700}\right)$, chickpea $\left(\mathrm{CB}_{500}, \mathrm{CB}_{700}\right)$, maize $\left(\mathrm{MB}_{500}, \mathrm{MB}_{700}\right)$, reed $\left(\mathrm{RB}_{500}, \mathrm{RB}_{700}\right)$, olive $\left(\mathrm{OB}_{500}\right.$, $\left.\mathrm{OB}_{700}\right)$ and sugarbeet $\left(\mathrm{SB}_{500}, \mathrm{SB}_{700}\right)$ to study the physicochemical properties of biochars. All feedstocks were dried in oven at $60{ }^{\circ} \mathrm{C}$ for $24 \mathrm{~h}$ and then were placed in electric furnace (Shimifan Model F. 47, Iran) for $2 \mathrm{~h}$ with warming rate of $8{ }^{\circ} \mathrm{C} \mathrm{min}{ }^{-1}$ under oxygen-limited conditions. After pyrolysis, when materials temperature equals to room temperature, they were weighed and after grinding them for physicochemical experiments, they were passed through $0.5 \mathrm{~mm}$ mesh. The physicochemical properties included yield $\%$, ash $\%, \mathrm{pH}, \mathrm{EC}, \mathrm{CEC}$, specific surface area, assimilated carbon\%, volatile material\% elements ( $\mathrm{CHNO}$ ) analysis, and molar ratio of $\mathrm{H} / \mathrm{C}$ and $\mathrm{O} / \mathrm{C}$. The study results were analyzed using SAS 9.3 and means were compared based on LSD. Due to high importance of specific surface area, porosity and CEC in metal pollutants reductions (Komkiene and Baltrenaits, 2016) three biochars with high specific surface area and high CEC and oxygen factor groups like carboxyl and hydroxyl groups were chosen for pot experiments. Biochars $\mathrm{MB}_{700}, \mathrm{WB}_{700}$, and $\mathrm{RB}_{700}$ were final selections.

\section{Pot experiment}

In order to find the impacts different amounts of selected biochars $\left(\mathrm{MB}_{700}, \mathrm{WB}_{700}\right.$, and $\mathrm{RB}_{700}$ ) on soil physicochemical properties ( $\mathrm{pH}, \mathrm{EC}, \mathrm{OC}$, amount of cadmium, nickel, and lead in soil and plant materials) and plant properties (leaf area, root and shoot dry matter), a pot experiment was conducted in June 2017, as factorial based on complete random design with three replications in Mahidasht Research Center in Kermanshah (Iran). The study results were analyzed using SAS 9.3 and means were compared based on LSD.

About $82 \mathrm{~kg}$ soil, classified as fine mixed thermic typic calcixerepts, was used to fill the pots and a sample of soil was used to determine its physicochemical properties. 
Each pot ( $250 \mathrm{~mm}$ height and $240 \mathrm{~mm}$ diameter) was filled by $3 \mathrm{~kg}$ soil. The selected three biochars at same level were added to pots. Preventing soil wash by irrigation, plastic nets were applied at the bottom of each pot. Three seeds corn (Zea mays L.) were planted at depth of $5 \mathrm{~mm}$ in each pot. All pots were irrigated up to field capacity by polluted water with $\mathrm{Cd}, \mathrm{Ni}$, and $\mathrm{Pb}$ at 1000, 2000, and 3000 microgram per liter, respectively, for two months. Ten days after emergence, two of seedlings were removed, and plants were harvested two months after sowing. At final harvest, leaf area was measured by leaf area meter (CID Bio-Science model CI-202, USA). After harvest, shoots and roots were separated, roots were washed by tap water and then by deionized water to remove soil and any remained biochar. Both shoots and roots were dried at $60{ }^{\circ} \mathrm{C}$ till to get a constant weight and then were grinded. Finally, a soil sample was taken from each pot.

\section{Analysis of biochar physicochemical properties}

Biochar production was obtained as (Sadaka et al., 2014; Zhao et al., 2017) the ratio of biochar weight to initial material weight (dried at $60{ }^{\circ} \mathrm{C}$ ) and percentage of volatiles and ash were determined at two temperatures of $750{ }^{\circ} \mathrm{C}$ and $950{ }^{\circ} \mathrm{C}$ according to the procedure of American Society for Testing and Material (ASTM). To measure the $\mathrm{pH}$, biochar was mixed with deionized water as ratio (W/V) of 1:20 then was on shaker for $1.5 \mathrm{~h}$ (Rajkovich et al., 2012) and finally samples were taken to determine $\mathrm{pH}$ by using pH meter (Metrohm model 691, Switzerland).

Biochar was mixed with deionized water as ratio of 1:10, was on shaker for $1 \mathrm{~h}$ and then by using conductivity meter (Jenway model 4010, UK) electrical conductivity was determined (Yang et al., 2015). Cation exchange capacity was determined by using NH4OAC solution (Melo et al., 2013; Song and Guo, 2012) and specific surface area was determined based on Brunauer-Emmett-Teller (BET) method (Brunauer et al., 1937). Biochars functional group were studied using Fourier-transform infrared (FTIR) spectrometer (Bruker model vertex 70, Germany) at wavelengths of 500-4000 nm. Biochar elemental composition (CHN) was measured by elemental analyzer (Costech model ECS4010, Italy). Oxygen percentage was calculated as:

$$
\mathrm{O}(\%)=100-(\mathrm{C} \%+\mathrm{H} \%+\mathrm{N} \%+\mathrm{Ash} \%)
$$

and molar element ratios, $\mathrm{O} / \mathrm{C}$ and $\mathrm{H} / \mathrm{C}$ were calculated as well. Nutrients of $\mathrm{MB}_{700}$, $\mathrm{RB}_{700}, \mathrm{WB}_{700}$ samples including $\mathrm{P}, \mathrm{K}, \mathrm{Ca}, \mathrm{Mg}, \mathrm{Zn}, \mathrm{Fe}$, and trace elements $(\mathrm{Pb}, \mathrm{Ni}$, and $\mathrm{Cd})$ were measured using peroxide hydrogen $\left(\mathrm{H}_{2} \mathrm{O}_{2}\right.$ digestion) and sulfuric acid $\left(\mathrm{H}_{2} \mathrm{SO}_{4}\right)$ (Wolf, 1982). All samples were tested by atomic absorption (Perkin Elmer Model 1100 D) while $\mathrm{Na}$ and $\mathrm{K}$ were tested by flame photometer (Jenway model PFP7, UK) and P by spectrometer (Apel Model PD303S, Japan).

\section{Soil physicochemical properties analyses}

Soil $\mathrm{pH}$ was determined by using paste saturation method (Metrohm 691, Switzerland $\mathrm{pH}$ meter) and EC were measured using EC meter (Jenway model 4010, UK). Phosphorous was measured according to Olsen method by using a spectrophotometer, (Apel model PD 303S, Japon) and potassium (ammonium acetate extract) was determined using a flame photometer (Jemway model PFP7, Japon). Organic carbon (wet ash method) and total neutralization value ( $\mathrm{TNV} \%)\left(\mathrm{CaCO}_{3}\right)$ were measured using neutralization with 
1N HCl. The bioavailable $\mathrm{Cd}, \mathrm{Ni}$ and $\mathrm{Pb}$ content of soil were determined by DTPA method $\left(0.005 \mathrm{~mol} \mathrm{~L}^{-1}\right.$ DTPA and $0.01 \mathrm{~mol} \mathrm{~L}^{-1} \mathrm{CaCl}_{2}$ and $0.01 \mathrm{~mol} \mathrm{~L}^{-1}$ triethylamine) (Lindsay and Norvell, 1978) using an atomic absorption spectrophotometer (PerkinElmer model 1100 D, USA).

\section{Feedstock and maize plant analysis}

All elements including the heavy metals of feedstock samples and maize plant shoots and roots were measured using dry ash and digest in $\mathrm{HCl}$ extraction methods by flame photometer and spectrophotometry and atomic absorption.

\section{Results and discussion}

\section{Biochar properties}

Biochar properties (Table 1) showed that with increasing temperature from $500{ }^{\circ} \mathrm{C}$ to $700{ }^{\circ} \mathrm{C}$ biochar production reduced but their ash increased. This is consistent with Rajkovich et al. (2012) study. Low production of biochar due to high temperature may be due to cracking of organic matter and gases drift (Zhang et al., 2015). In this study the highest production $\left(34.17 \%\right.$ ) was for $\mathrm{WB}_{500}$ and in the second rank was $\mathrm{CB}_{500}$ by $33.93 \%$. Results also showed that increasing temperature (pyrolysis temperature) significantly reduced volatile matter percentage (Table 1), which is consistent with Rajkovich et al. (2012). Reduction of volatile matter percentage can be due to water loss and organic material (cellulose, hemicellulose, and lignin) decomposition during pyrolysis (Sadaka et al., 2014). Increasing pyrolysis temperature significantly $(\mathrm{P}<0.05)$ increased $\mathrm{pH}$ and EC as well (Table 1). Similarly, Jindo et al. (2014) reported that increasing temperature to $700{ }^{\circ} \mathrm{C}$ increased the biochar. Samples of $\mathrm{pH}$ and EC were 9.06-10.14 and 167.7-760 $\mathrm{mS} / \mathrm{m}$ respectively. Increasing $\mathrm{pH}$ and $\mathrm{EC}$ may be due to increasing of ash (Wu et al., 2012; Paz-Ferreiro et al., 2014; da Silva et al., 2017; Novak et al., 2009).

Table 1. Physical and chemical characteristic of biochars (values are mean of three replications)

\begin{tabular}{|c|c|c|c|c|c|c|c|c|c|c|c|c|c|c|c|c|}
\hline \multirow[b]{2}{*}{ Biochar } & \multicolumn{2}{|c|}{ Yield (\%) } & \multicolumn{2}{|c|}{ pH } & \multicolumn{2}{|c|}{ Dry ash $(\%)$} & \multicolumn{2}{|c|}{ VM (\%) } & \multicolumn{2}{|c|}{$\begin{array}{c}\text { Fixed carbon } \\
(\%)\end{array}$} & \multicolumn{2}{|c|}{$\mathrm{EC}\left(\mathrm{mS} \mathrm{m}^{-1}\right)$} & \multicolumn{2}{|c|}{ BET $\left(\mathbf{m}^{2} \mathbf{g}^{-1}\right)$} & \multicolumn{2}{|c|}{ CEC $\left(\mathrm{Cm} \mathrm{kg}^{-1}\right)$} \\
\hline & $500{ }^{\circ} \mathrm{C}$ & $700^{\circ} \mathrm{C}$ & $500{ }^{\circ} \mathrm{C}$ & $700^{\circ} \mathrm{C}$ & $500{ }^{\circ} \mathrm{C}$ & $700^{\circ} \mathrm{C}$ & $500{ }^{\circ} \mathrm{C}$ & $700^{\circ} \mathrm{C}$ & $500{ }^{\circ} \mathrm{C}$ & $700{ }^{\circ} \mathrm{C}$ & $500{ }^{\circ} \mathrm{C}$ & $700^{\circ} \mathrm{C}$ & 500 & $700^{\circ} \mathrm{C}$ & $500{ }^{\circ} \mathrm{C}$ & $700^{\circ} \mathrm{C}$ \\
\hline WB & $34.17^{\mathrm{a}}$ & $29.07^{\mathrm{cd}}$ & $9.39^{\mathrm{bcd}}$ & $10.13^{\mathrm{a}}$ & $25.86^{\mathrm{b}}$ & $29.91^{\mathrm{a}}$ & $40.57^{\mathrm{c}}$ & $32.28^{\mathrm{e}}$ & $33.57^{g}$ & $38.05^{\mathrm{f}}$ & $410.0^{\mathrm{e}}$ & $578.3^{\mathrm{c}}$ & $4.14^{\mathrm{g}}$ & $142.2^{\mathrm{b}}$ & $16.17^{\mathrm{f}}$ & $20.52^{\mathrm{cd}}$ \\
\hline $\mathrm{RB}$ & $27.80^{\mathrm{d}}$ & $25.70^{\mathrm{e}}$ & $9.06^{\mathrm{d}}$ & $9.74^{\mathrm{abc}}$ & $8.98^{\mathrm{gh}}$ & $12.48^{\mathrm{f}}$ & $43.97^{\mathrm{b}}$ & $36.05^{\mathrm{d}}$ & $47.05^{\mathrm{de}}$ & $51.47^{\mathrm{c}}$ & $410.3^{e}$ & $462.3^{d}$ & $3.29^{\mathrm{g}}$ & $241.1^{\mathrm{a}}$ & $12.86^{\mathrm{g}}$ & $19.77^{\mathrm{cd}}$ \\
\hline MB & $29.53^{\mathrm{bcd}}$ & $25.17^{\mathrm{e}}$ & $9.35^{\mathrm{cd}}$ & $9.97^{\mathrm{a}}$ & $9.50^{\mathrm{g}}$ & $12.47^{\mathrm{f}}$ & $43.20^{\mathrm{bc}}$ & $24.84^{\mathrm{gh}}$ & $47.30^{\mathrm{de}}$ & $62.69^{\mathrm{b}}$ & $167.7^{\mathrm{g}}$ & $214.3^{\mathrm{f}}$ & $5.28^{\mathrm{g}}$ & $97.89^{\mathrm{c}}$ & $18.90^{\mathrm{de}}$ & $21.60^{\mathrm{bc}}$ \\
\hline $\mathrm{CB}$ & $33.93^{\mathrm{a}}$ & $30.00^{\mathrm{bc}}$ & $9.41^{\text {bcd }}$ & $10.14^{\mathrm{a}}$ & $15.70^{\mathrm{e}}$ & $22.16^{\mathrm{c}}$ & $47.90^{\mathrm{a}}$ & $27.48^{\mathrm{fg}}$ & $36.40^{\mathrm{fg}}$ & $50.36^{\mathrm{cd}}$ & $540.0^{\mathrm{c}}$ & $760.0^{\mathrm{a}}$ & $3.41^{\mathrm{g}}$ & $23.17^{\mathrm{e}}$ & $22.84^{\mathrm{b}}$ & $11.01^{\mathrm{g}}$ \\
\hline OB & $29.70^{\mathrm{bc}}$ & $27.80^{\mathrm{d}}$ & $9.14^{\mathrm{d}}$ & $9.78^{\mathrm{ab}}$ & $7.47^{\mathrm{h}}$ & $9.75^{\mathrm{g}}$ & $28.20^{\mathrm{f}}$ & $21.70^{\mathrm{h}}$ & $64.33^{\mathrm{b}}$ & $68.55^{\mathrm{a}}$ & $206.0^{\mathrm{fg}}$ & $398.7^{\mathrm{e}}$ & $6.64^{\mathrm{g}}$ & $82.39^{\mathrm{d}}$ & $17.25^{\mathrm{ef}}$ & $11.47^{\mathrm{g}}$ \\
\hline SB & $31.20^{\mathrm{b}}$ & $24.70^{\mathrm{e}}$ & $9.30^{\mathrm{d}}$ & $10.08^{\mathrm{a}}$ & $17.89^{\mathrm{d}}$ & $15.36^{\mathrm{e}}$ & $35.93^{\mathrm{d}}$ & $31.59^{\mathrm{e}}$ & $46.18^{e}$ & $53.05^{\mathrm{c}}$ & $400.3^{\mathrm{e}}$ & $631.3^{\mathrm{b}}$ & $3.40^{\mathrm{g}}$ & $11.18^{\mathrm{f}}$ & $25.78^{\mathrm{a}}$ & $11.82^{\mathrm{g}}$ \\
\hline $\begin{array}{l}\text { LSD } \\
(5 \%)\end{array}$ & \multicolumn{2}{|c|}{1.78} & \multicolumn{2}{|c|}{0.43} & \multicolumn{2}{|c|}{1.62} & \multicolumn{2}{|c|}{3.33} & \multicolumn{2}{|c|}{3.90} & \multicolumn{2}{|c|}{39.92} & \multicolumn{2}{|c|}{4.12} & \multicolumn{2}{|c|}{1.98} \\
\hline
\end{tabular}

Different letters indicate significant differences between treatments $\mathrm{P}<0.05$

BET and CEC results (Table 1) indicated that specific surface and CEC of biochars (WB, RB and $\mathrm{MB}$ ) significantly increased as the temperature increased from $500{ }^{\circ} \mathrm{C}$ to $700{ }^{\circ} \mathrm{C}$. Increase of biochar specific surface due to high temperature can be the result of organic matter degradation and developing pores and channels in biochar during pyrolysis (Zhao et al., 2017) and CEC increase can be due to change of negative charge 
in relation to $\mathrm{pH}$ (da Silva et al., 2017) and specific surface area rise. Komkiene and Baltrenaite (2016) resulted that by increasing temperature from $450{ }^{\circ} \mathrm{C}$ to $700{ }^{\circ} \mathrm{C}$ specific surface area of two types of biochar increased from 9.6 to 10.4 and 5.92 to $7.17 \mathrm{~m}^{2} \mathrm{~g}^{-1}$ which is similar to this study results.

Elemental analysis and determination of ratios $\mathrm{O} / \mathrm{C}$ and $\mathrm{H} / \mathrm{C}$ are most important indices for realization of aromaticity and maturity of biochars (Schmidt and Noack, 2000; Nguyen and Lehmann, 2009). Results of analysis (Table 2) showed that by increasing pyrolysis temperature, carbon percentage of biochar samples increased while $\mathrm{H}, \mathrm{N}, \mathrm{O}$ and ratios $\mathrm{H} / \mathrm{C}, \mathrm{O} / \mathrm{C}$ reduced. Reduction of $\mathrm{O}$ and $\mathrm{H}$ can be the result of removal of water and oxygen from hydroxyl and carboxyl agents (Wang et al., 2015). The highest $(84.75 \%)$ and lowest $(43.19 \%)$ carbon percentage were from $\mathrm{OB}_{700}$ and $\mathrm{SB}_{500}$ respectively. Melo et al. (2013) and Jindo et al. (2014) showed that by increasing pyrolysis temperature from $500{ }^{\circ} \mathrm{C}$ to $700{ }^{\circ} \mathrm{C}$, carbon $\%$, hydrogen $\%, \mathrm{~N} \%$ and molar ratio of $\mathrm{H} / \mathrm{C}$ and $\mathrm{O} / \mathrm{C}$ of biochar increased as well which are also consistent with our results.

Table 2. Elemental analysis of biochars, $\mathrm{H} / \mathrm{C}$ and $\mathrm{O} / \mathrm{C}$ ratios (values are mean of three replications)

\begin{tabular}{|c|c|c|c|c|c|c|c|c|c|c|c|c|}
\hline \multirow[b]{3}{*}{ Biochar } & \multicolumn{2}{|c|}{$\mathbf{N}$} & \multicolumn{2}{|c|}{ C } & \multicolumn{2}{|c|}{ H } & \multicolumn{2}{|c|}{ O* } & \multicolumn{2}{|c|}{$\mathrm{H} / \mathrm{C}$} & \multicolumn{2}{|c|}{$\mathrm{O} / \mathrm{C}$} \\
\hline & \multicolumn{8}{|c|}{$\%$} & \multicolumn{4}{|c|}{ Molar ratio } \\
\hline & $500{ }^{\circ} \mathrm{C}$ & $700{ }^{\circ} \mathrm{C}$ & $500{ }^{\circ} \mathrm{C}$ & $700{ }^{\circ} \mathrm{C}$ & $500{ }^{\circ} \mathrm{C}$ & $700{ }^{\circ} \mathrm{C}$ & $500{ }^{\circ} \mathrm{C}$ & $700{ }^{\circ} \mathrm{C}$ & $500{ }^{\circ} \mathrm{C}$ & $700^{\circ} \mathrm{C}$ & $500^{\circ} \mathrm{C}$ & $700^{\circ} \mathrm{C}$ \\
\hline WB & $0.67^{\mathrm{b}}$ & $0.35^{\mathrm{def}}$ & $54.12^{\mathrm{f}}$ & $60.84^{\mathrm{de}}$ & $2.60^{\mathrm{a}}$ & $1.25^{\mathrm{d}}$ & $20.33^{\mathrm{d}}$ & $8.48^{\mathrm{g}}$ & $0.58^{\mathrm{a}}$ & $0.25^{\mathrm{c}}$ & $0.28^{\mathrm{d}}$ & $0.10^{\mathrm{gh}}$ \\
\hline $\mathrm{RB}$ & $0.47^{\mathrm{cd}}$ & $0.28^{\mathrm{f}}$ & $55.11^{\mathrm{f}}$ & $75.80^{\mathrm{b}}$ & $2.60^{\mathrm{a}}$ & $1.39^{\mathrm{d}}$ & $33.42^{\mathrm{b}}$ & $10.82^{\mathrm{f}}$ & $0.56^{\mathrm{a}}$ & $0.22^{\mathrm{cd}}$ & $0.45^{\mathrm{b}}$ & $0.11^{\mathrm{g}}$ \\
\hline MB & $0.82^{\mathrm{a}}$ & $0.41^{\text {cde }}$ & $68.91^{\mathrm{c}}$ & $78.22^{\mathrm{b}}$ & $2.72^{\mathrm{a}}$ & $1.81^{\mathrm{c}}$ & $18.6^{\mathrm{e}}$ & $7.80^{\mathrm{gh}}$ & $0.47^{\mathrm{b}}$ & $0.28^{c}$ & $0.20^{\mathrm{f}}$ & $0.07^{\mathrm{i}}$ \\
\hline $\mathrm{CB}$ & $0.89^{\mathrm{a}}$ & $0.48^{\mathrm{c}}$ & $63.09^{\mathrm{d}}$ & $70.13^{c}$ & $2.67^{\mathrm{a}}$ & $1.25^{\mathrm{d}}$ & $18.2^{\mathrm{e}}$ & $6.75^{\mathrm{hi}}$ & $0.51^{\mathrm{ab}}$ & $0.21^{\mathrm{cd}}$ & $0.22^{\mathrm{e}}$ & $0.07^{\mathrm{i}}$ \\
\hline OB & $0.88^{\mathrm{a}}$ & $0.38^{\text {cdef }}$ & $59.25^{\mathrm{e}}$ & $84.75^{\mathrm{a}}$ & $2.23^{\mathrm{b}}$ & $1.85^{\mathrm{c}}$ & $30.73^{c}$ & $5.40^{\mathrm{i}}$ & $0.45^{\mathrm{b}}$ & $0.26^{\mathrm{c}}$ & $0.39^{c}$ & $0.05^{\mathrm{j}}$ \\
\hline SB & $0.79^{\mathrm{ab}}$ & $0.31^{\mathrm{ef}}$ & $43.19^{\mathrm{g}}$ & $75.33^{b}$ & $1.82^{\mathrm{c}}$ & $1.06^{\mathrm{d}}$ & $36.89^{\mathrm{a}}$ & $8.70^{\mathrm{g}}$ & $0.51^{\mathrm{ab}}$ & $0.17^{\mathrm{d}}$ & $0.64^{\mathrm{a}}$ & $0.09^{\mathrm{h}}$ \\
\hline $\begin{array}{l}\text { LSD } \\
(5 \%)\end{array}$ & \multicolumn{2}{|c|}{0.125} & \multicolumn{2}{|c|}{3.305} & \multicolumn{2}{|c|}{0.361} & \multicolumn{2}{|c|}{1.663} & \multicolumn{2}{|c|}{0.072} & \multicolumn{2}{|c|}{0.014} \\
\hline
\end{tabular}

*Determined by difference. Different letters indicate significant differences between treatments $\mathrm{P}<0.05$

FTIR spectrum of selected biochar at two different temperatures are presented in Figure 1.

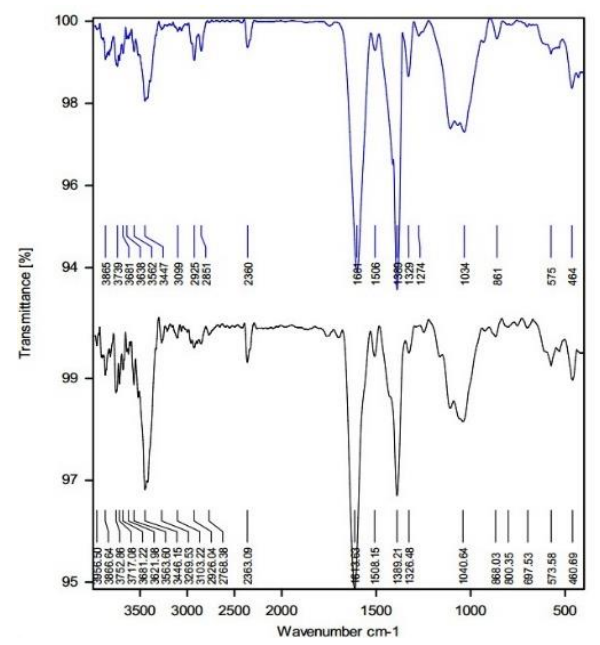



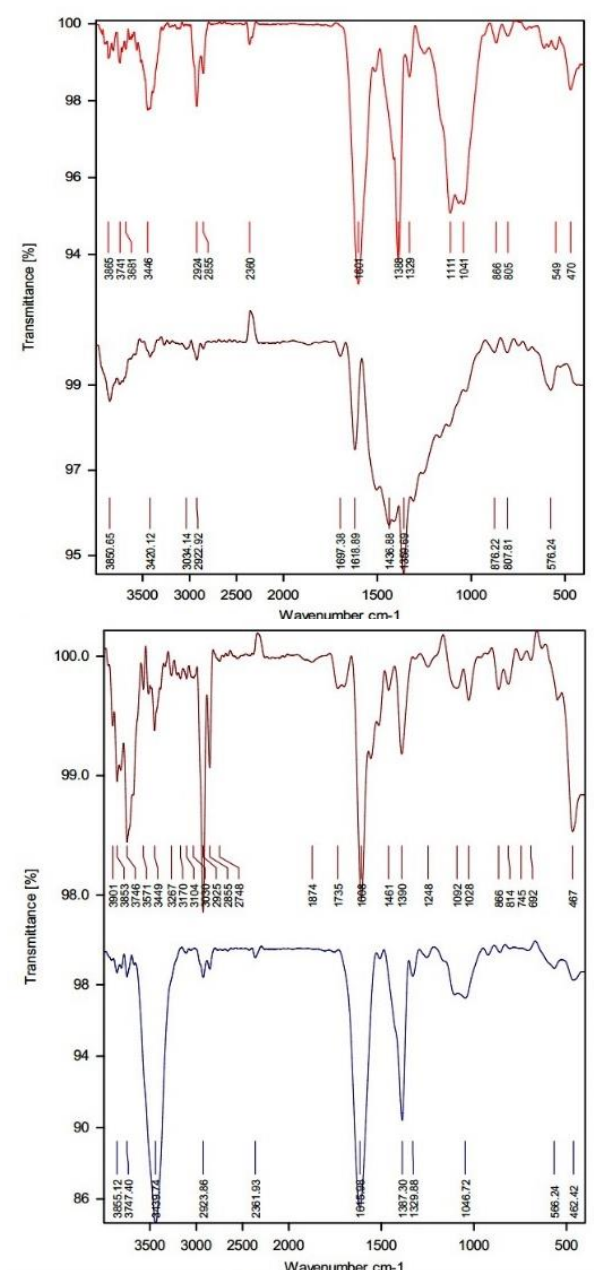

Figure 1. Biochar spectrum for $M B, R B$, and $W B$

As temperature increased a reduction of $\mathrm{O}-\mathrm{H}$ stretching $\left(3680 \mathrm{~cm}^{-1}\right)$ was observed within FTIR spectrum which may be due to dehydration of biomass and reduction of polarity during pyrolysis.

\section{Effect of biochar on soil $\mathrm{pH}, \mathrm{EC}$ and $\mathrm{OC}$}

The results indicated that the effect of biochar type (Table 3) and amount were significant on soil pH, OC and EC (Fig. 2A, B,C). Comparison of means showed that $\mathrm{WB}_{700}$ was more effective in increasing soil $\mathrm{pH}$ compared to $\mathrm{MB}_{700}$ or $\mathrm{RB}_{700}$ (Table 3). $\mathrm{WB}_{700}$ and $\mathrm{MB}_{700}$ significantly $(\mathrm{P}<0.05)$ increased soil $\mathrm{EC}$ and $\mathrm{OC}$ (Table 3). Although the effects of $\mathrm{MB}_{700}$ and $\mathrm{RB}_{700}$ on soil $\mathrm{OC}$ were similar, these biochars were more effective than $\mathrm{WB}_{700}$. Similarly, there was no significant $(\mathrm{P}<0.05)$ difference between $\mathrm{WB}_{700}$ and $\mathrm{RB}_{700}$ in terms of soil $\mathrm{EC}$, but these biochars were more effective than $\mathrm{MB}_{700}$. Results showed (Tables 1 and 4) that biochars $\mathrm{pH}$ were 10.13, 9.74, and 9.97 for $\mathrm{WB}_{700}, \mathrm{RB}_{700}$ and $\mathrm{MB}_{700}$, respectively, whereas soil $\mathrm{pH}$ was 7.52 . Therefore, it should be expected that soil $\mathrm{pH}$ may increase as a result of biochar application in soil. Albuquerque et al. (2011) and $\mathrm{Xu}$ (2012) showed that adding biochar to soil increased the $\mathrm{pH}$. da Silva et al. (2017) showed that adding 3 biochar types at highest amount into 
the soil not only increased $\mathrm{pH}$ by 0.76 to 1.68 , but also soil organic carbon content also linearly increased. These results are consistent with this study results. Soil $\mathrm{pH}$ increase may be due to high biochar ash and its components. The ash product from pyrolysis contains oxide and hydroxide of alkali metals which are easily dissolve in water and are able to increase soil pH (da Silva et al., 2017). Further to ash, type of feedstock has also shown effects on pH and EC (Qayyum et al., 2015; Abdelhafez et al., 2014). Qayyum et al. (2015) showed that from 9 different biochars, 5 of them were able to increase soil $\mathrm{EC}, 3$ of them increased soil $\mathrm{pH}$ and one did not show any significant $(\mathrm{P}<0.05)$ effect on soil $\mathrm{pH}$ and EC. Biochars properties depend on factors such as feedstock type, feedstock size, pyrolysis temperature and retention time in oven (Paz-Ferreiro et al., 2014). In our study increasing biochar dose (Fig. $2 A, B$ and $C$ ) led to increasing soil pH, EC and OC (except MB 700 for EC). Similary, some studies have shown that increasing biochar dose would increase soil organic matter (Dume et al., 2016; da Silva et al., 2014) as well as soil EC (Abdelhafez et al., 2014; Yang et al., 2015).

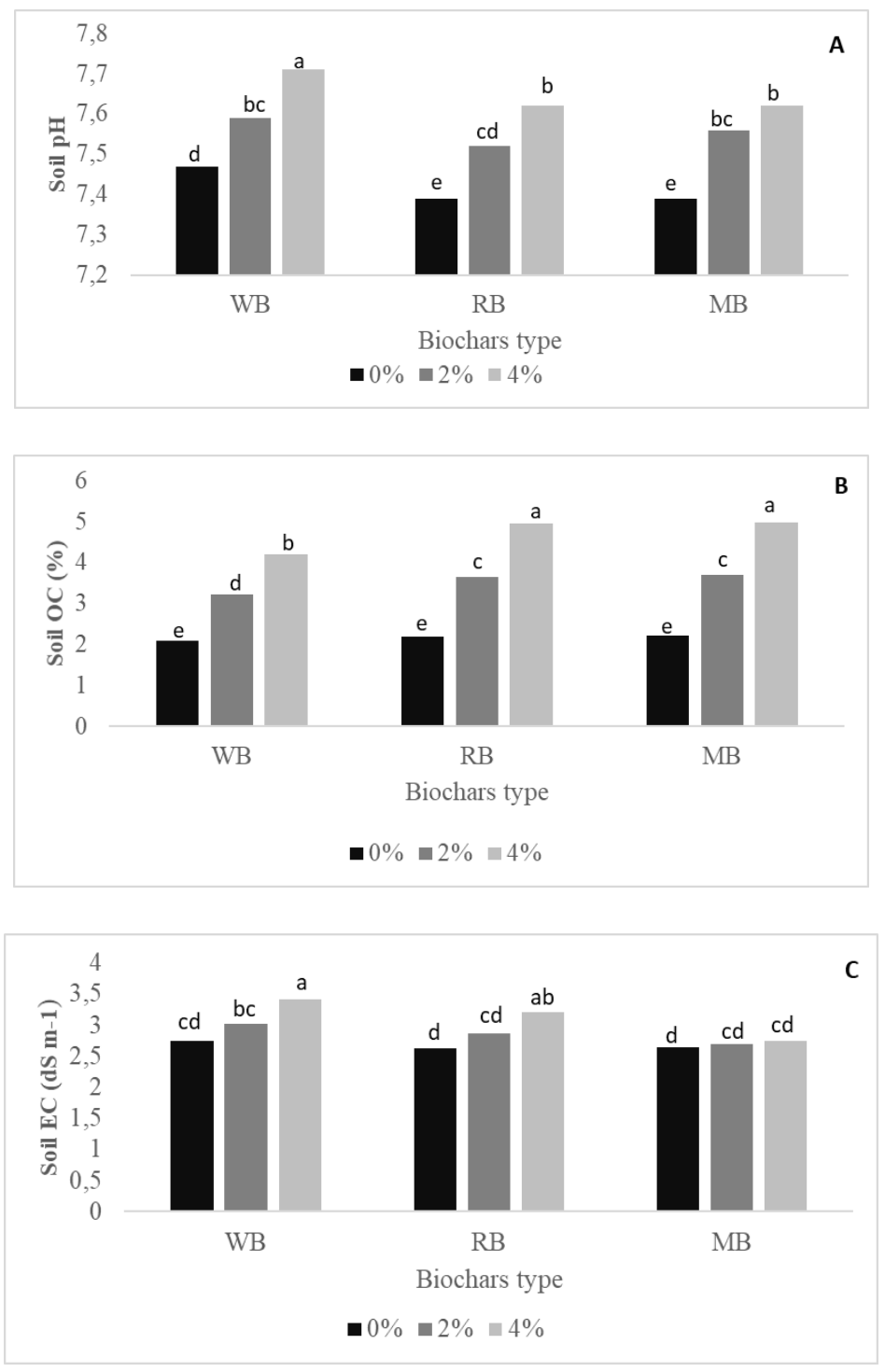

Figure 2. Effect of different rates of biochars on soil $p H(A), O C(B)$ and $E C(C)$ 
Table 3. Effect of biochar types on shoot, root, soil properties, plant indices and translocation factor (values are mean of three replications)

\begin{tabular}{|c|c|c|c|c|c|c|c|c|c|c|c|c|c|c|c|c|c|c|c|}
\hline \multirow{3}{*}{$\begin{array}{c}\text { Biochar } \\
\text { types }\end{array}$} & \multicolumn{3}{|c|}{ Shoot } & \multicolumn{3}{|c|}{ Root } & \multicolumn{6}{|c|}{ Soil } & \multicolumn{5}{|c|}{ Plant } & \multicolumn{2}{|c|}{ TF value } \\
\hline & Cd & $\mathrm{Ni}$ & $\mathbf{P b}$ & Cd & $\mathrm{Ni}$ & $\mathbf{P b}$ & Cd & $\mathrm{Ni}$ & $\mathbf{P b}$ & pH & EC & OC & LA & Shoot & Root & $R: S$ & $\mathbf{T F}_{\mathrm{Cd}}$ & $\mathbf{T F}_{\mathrm{Ni}}$ & $\mathbf{T F}_{\mathrm{Pb}}$ \\
\hline & \multicolumn{9}{|c|}{$\mathrm{mg} \mathrm{kg}^{-1}$} & & $d S / m$ & $\%$ & $\mathrm{~cm}^{2}$ & \multicolumn{2}{|c|}{ gr } & & & & \\
\hline WB & $0.56^{\mathrm{b}}$ & $1.22^{\mathrm{a}}$ & $3.35^{\mathrm{a}}$ & $2.26^{\mathrm{a}}$ & $3.61^{\mathrm{a}}$ & $6.24^{\mathrm{a}}$ & $0.41^{\mathrm{a}}$ & $2.41^{\mathrm{c}}$ & $2.38^{\mathrm{a}}$ & $7.58^{\mathrm{a}}$ & $3.06^{\mathrm{a}}$ & $3.17^{\mathrm{b}}$ & $294.7^{\mathrm{c}}$ & $7.04^{\mathrm{b}}$ & $1.71^{\mathrm{c}}$ & $4.11^{\mathrm{a}}$ & $0.24^{\mathrm{b}}$ & $0.34^{\mathrm{a}}$ & $0.53^{\mathrm{a}}$ \\
\hline $\mathrm{RB}$ & $0.60^{\mathrm{a}}$ & $1.24^{\mathrm{a}}$ & $2.75^{\mathrm{b}}$ & $2.25^{\mathrm{a}}$ & $3.60^{\mathrm{a}}$ & $6.36^{\mathrm{a}}$ & $0.41^{\mathrm{ab}}$ & $2.81^{\mathrm{a}}$ & $2.33^{\mathrm{a}}$ & $7.50^{\mathrm{b}}$ & $2.89^{\mathrm{a}}$ & $3.59^{\mathrm{a}}$ & $322.6^{\mathrm{b}}$ & $7.34^{\mathrm{a}}$ & $1.85^{\mathrm{b}}$ & $3.96^{\mathrm{b}}$ & $0.27^{\mathrm{a}}$ & $0.34^{\mathrm{a}}$ & $0.41^{\mathrm{b}}$ \\
\hline MB & $0.57^{\mathrm{b}}$ & $1.23^{\mathrm{a}}$ & $2.69^{\mathrm{b}}$ & $2.03^{\mathrm{b}}$ & $3.68^{\mathrm{a}}$ & $6.20^{\mathrm{a}}$ & $0.39^{\mathrm{b}}$ & $2.56^{\mathrm{b}}$ & $2.33^{\mathrm{a}}$ & $7.52^{\mathrm{b}}$ & $2.70^{\mathrm{b}}$ & $3.62^{\mathrm{a}}$ & $330.8^{\mathrm{a}}$ & $7.37^{\mathrm{a}}$ & $1.87^{\mathrm{a}}$ & $3.93^{\mathrm{b}}$ & $0.28^{\mathrm{a}}$ & $0.31^{\mathrm{b}}$ & $0.41^{\mathrm{b}}$ \\
\hline $\begin{array}{l}\text { LSD } \\
(0.01)\end{array}$ & \begin{tabular}{|c|}
0.02 \\
2
\end{tabular} & 0.072 & 0.091 & 0.045 & 0.112 & 0.234 & 0.013 & 0.064 & 0.125 & 0.045 & 0.187 & 0.182 & 4.342 & 0.078 & 0.018 & 0.045 & 0.012 & 0.018 & 0.012 \\
\hline
\end{tabular}

Different letters indicate significant differences between treatments $\mathrm{P}<0.05$

Table 4. Soil physicochemical analyses

\begin{tabular}{|c|c|c|c|c|c|c|c|c|c|c|c|c|c|}
\hline \multirow{2}{*}{$\mathbf{p H}$} & EC & TNV & OC & $\mathbf{N}$ & $\mathbf{P}$ & $\mathbf{K}$ & Mn & $\mathrm{Fe}$ & $\mathbf{Z n}$ & $\mathbf{C u}$ & Cd & $\mathrm{Ni}$ & $\mathbf{P b}$ \\
\hline & $\mathrm{dS} / \mathrm{m}$ & \multicolumn{3}{|c|}{$\%$} & \multicolumn{9}{|c|}{$\mathrm{mg} \mathrm{kg}^{-1}$} \\
\hline 7.52 & 2.12 & 32.5 & 2.19 & 0.22 & 21 & 1120 & 23.4 & 11.40 & 4.12 & 2.34 & 0.31 & 1.51 & 2.1 \\
\hline
\end{tabular}

\section{Effect of biochar on bioavailability of $\mathrm{Cd}$, Ni and $\mathrm{Pb}$ in soil}

Mean comparison (Table 3) showed that biochar types differ in their reducing effect on $\mathrm{Cd}$ and $\mathrm{Ni}$ bioavailability, whereas there was no significant $(\mathrm{P}<0.05)$ difference between them for effect on $\mathrm{Pb}$. The amended soil with $\mathrm{MB}_{700}$ showed less bioavailable $\mathrm{Cd}$ in comparison to $\mathrm{WB}_{700}$ or $\mathrm{RB}_{700}$. There was no significant $(\mathrm{P}<0.05)$ difference between $\mathrm{WB}_{700}$ and $\mathrm{RB}_{700}$. The effect of $\mathrm{WB}_{700}$ in reducing soil bioavailable $\mathrm{Ni}$ concentration was more pronounced compared to $\mathrm{RB}_{700}$ or $\mathrm{MB}_{700}$. Increasing biochar does significantly $(\mathrm{P}<0.05)$ decreased bioavailable $\mathrm{Cd}, \mathrm{Ni}$, and $\mathrm{Pb}$ compared to control (0.00\% application) (Fig. 3A, B and $C$ ). In comparison with control, application of $4 \%$ biochar decreased bioavailable $\mathrm{Cd}, \mathrm{Ni}$, and $\mathrm{Pb}$ by $58.8 \%, 46 \%$ and $76 \%$, respectively. Increasing soil $\mathrm{pH}$ may lead to $\mathrm{Cd}$ precipitation as $\mathrm{Cd}\left(\mathrm{CO}_{3}\right)$ (Mousavi et al., 2011) and lead to precipitation as pb5 $\left(\mathrm{PO}_{4}\right)_{3} \mathrm{Cl}$ (Kopittke et al., 2008). In addition, increasing soil $\mathrm{pH}$ increases binding metal ions by $\mathrm{pH}$ dependent surface ligands (Uchimiya et al., 2011). The effect of biochar depends highly on the type of pollutant metal (Uchimiya et al., 2010). Lead in soil highly depends to organic matter and by increasing $\mathrm{pH}$, lead stability (Karami et al., 2011) and also Cd and Ni stability (Yang et al., 2015) will increase. According to Park et al. (2011) and Fellet et al. (2011) adding biochar to soil decreases bioavailability of $\mathrm{Cd}$ and $\mathrm{Pb}$ of soil. Similar to this study results, Cui et al. (2011) also reported lower Cd of soil as biochar was added to soil.

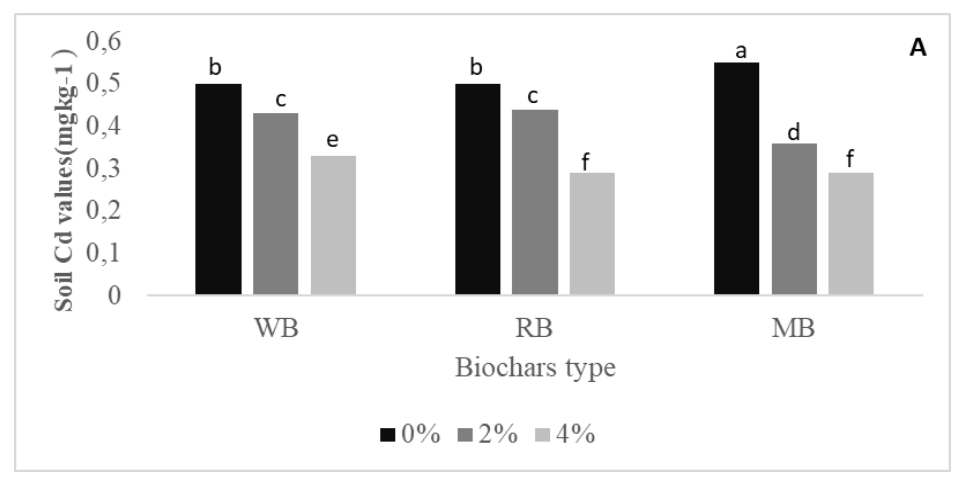




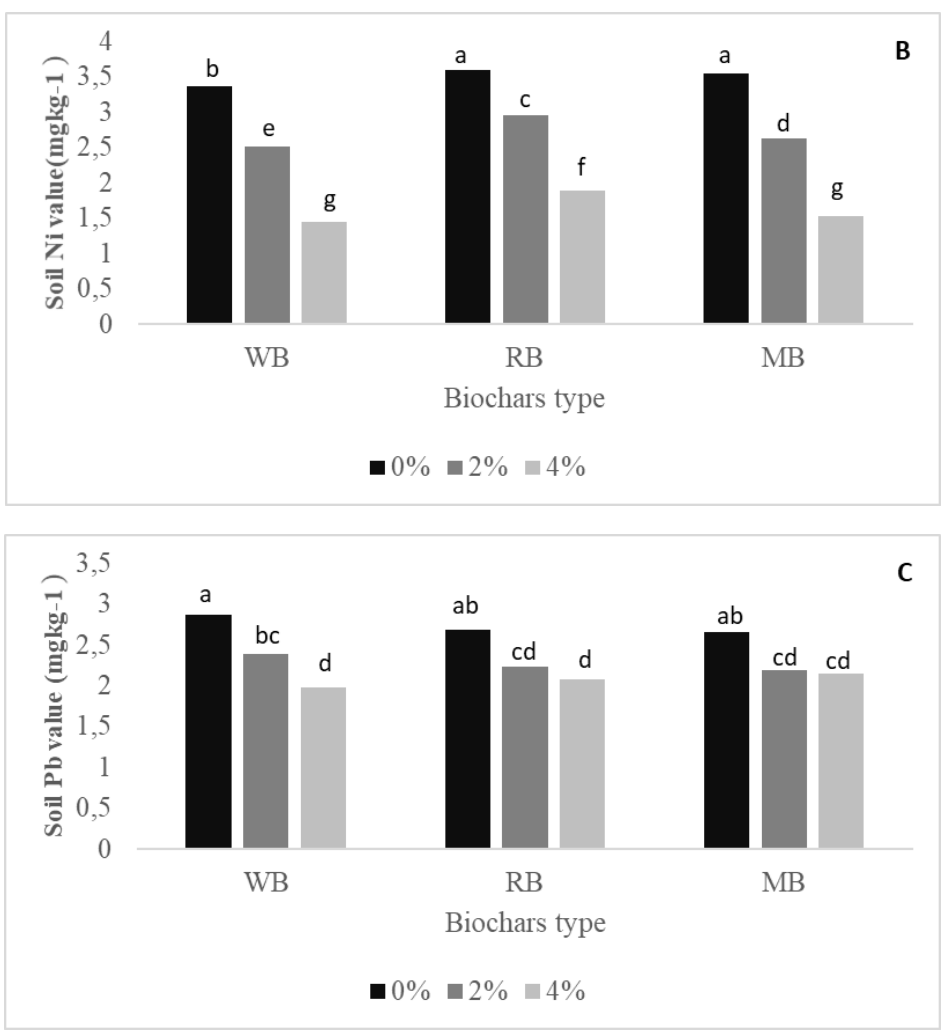

Figure 3. Effect of different rates of biochar different rates on soil bioavailable $\mathrm{Cd}(\mathrm{A}), \mathrm{Ni}(\mathrm{B})$ and $\mathrm{Pb}(\mathrm{C})$

The feedstock and three types of biochar ( $\mathrm{WB}_{700}, \mathrm{RB}_{700}$, and $\mathrm{MB}_{700}$ ) analysis (Tables 5 and 6 ) indicated that $\mathrm{P}, \mathrm{Na}, \mathrm{Ca}$, and $\mathrm{Mg}$ content in biochar are more compared to feedstocks. In addition, the soil $\mathrm{Ca}$ and $\mathrm{P}$ content were also high (Table 4). Increasing $\mathrm{P}$ availability due to biochar application plays a key role in $\mathrm{Pb}$ stabilization in water solution (Cao et al., 2009) and lead stabilization through precipitation or in complex with phosphate (Ahmad et al., 2014). Simultaneous release of elements $\mathrm{Na}, \mathrm{Ca}, \mathrm{K}, \mathrm{Mg}$, $\mathrm{P}$, and $\mathrm{S}$ from soil and biochar can result in stability of heavy metals (Uchimiya et al., 2011). In this study, $\mathrm{WB}_{700}, \mathrm{RB}_{700}$, and $\mathrm{MB}_{700}$, had O-containing functional groups (Fig. 1). These functional groups increase biochar effect (Yang et al., 2015; Ahmad et al., 2014) therefore they should be more effective for heavy metal stabilization especially in acidic soils with low CEC and organic matter (Uchimiya et al., 2011).

Table 5. Chemical analyses of three types of feedstocks

\begin{tabular}{c|c|c|c|c|c|c|c|c|c|c|c|c}
\hline \multirow{2}{*}{ Feedstock } & Cd & Ni & Pb & $\mathbf{C u}$ & $\mathbf{Z n}$ & $\mathbf{F e}$ & $\mathbf{M n}$ & $\mathbf{N}$ & $\mathbf{P}$ & $\mathbf{K}$ & $\mathbf{C a}$ & $\mathbf{M g}$ \\
\cline { 2 - 11 } & \multicolumn{10}{|c|}{$\mathbf{m g ~ k g}^{-1}$} \\
\hline Wheat residual & 0.23 & 1.14 & 1.38 & 10.8 & 25 & 80 & 18 & 1.22 & 0.16 & 1.10 & 0.33 & 0.18 \\
Reed (leave and stalk) & 0.1 & 1.0 & 0.90 & 8.3 & 23 & 65 & 13 & 1.03 & 0.11 & 0.92 & 0.37 & 0.25 \\
Maize residual & 0.27 & 1.25 & 1.61 & 14.7 & 32 & 87 & 25 & 2.12 & 0.25 & 1.42 & 0.30 & 0.21 \\
\hline
\end{tabular}


Table 6. Chemical composition of biochar

\begin{tabular}{c|c|c|c|c|c|c|c|c|c|c|c|c}
\hline \multirow{2}{*}{ Biochar } & Cd & Ni & Pb & $\mathbf{C u}$ & $\mathbf{Z n}$ & $\mathbf{F e}$ & $\mathbf{M n}$ & $\mathbf{P}$ & $\mathbf{K}$ & $\mathbf{C a}$ & $\mathbf{M g}$ & $\mathbf{N a}$ \\
\cline { 2 - 11 } & \multicolumn{10}{c}{$\mathbf{m g ~ k g}^{-1}$} \\
\hline WB700 & 0.63 & 2.2 & 2.1 & 20 & 85 & 360 & 156 & 3.6 & 29.7 & 8.2 & 6.5 & 6.8 \\
RB700 & 0.27 & 1.1 & 1.3 & 17 & 73 & 310 & 148 & 3.0 & 18.8 & 10.4 & 7.8 & 5.7 \\
MB700 & 0.71 & 2.6 & 2.7 & 27 & 89 & 395 & 175 & 4.2 & 38.0 & 9.0 & 6.9 & 4.9 \\
\hline
\end{tabular}

\section{Effect of biochar on $\mathrm{Cd}, \mathrm{Ni}$, and $\mathrm{Pb}$ uptake and translocation by maize}

Means comparison (Table 3) indicated that there was no significant difference between $\mathrm{MB}_{700}$ and $\mathrm{WB}_{700}$ biochars for $\mathrm{Cd}$ reduction in maize shoots but their effect was higher than $\mathrm{RB}_{700}$. In addition, this study results indicated that there was no significant difference between $\mathrm{MB}_{700}$ and $\mathrm{RB}_{700}$ for reducing $\mathrm{Pb}$ in maize shoots, however their effect was less than $\mathrm{WB}_{700}$. For reduction of $\mathrm{Ni}$ in shoots, results showed no significant $(\mathrm{P}<0.05)$ difference between biochars. This study revealed that $\mathrm{Cd}, \mathrm{Ni}$, and $\mathrm{Pb}$ concentrations significantly $(\mathrm{P}<0.05)$ decreased in both shoot and root of maize as biochar application increased (Fig. 4A, B, C). Kacálková et al. (2014) reported that increasing heavy metal concentration in soil increased their uptake by plants (Komkiene and Baltrenaite, 2016) also found that application of adsorbent materials into the soil decrease heavy metal uptake by plants. Reduction of metal concentration in plants due to biochar application may be related to immobilization of bioavailable metals and dilution effects of increased biomass (Park et al., 2011). In this study highest uptake of $\mathrm{Cd}, \mathrm{Ni}$ and $\mathrm{Pb}$ by corn plants was monitored when no biochar was applied into the soil while by adding $4 \%$ biochar the uptake of these metals was at minimum level. By increasing amount of biochar application, concentration of $\mathrm{Cd}, \mathrm{Ni}$ and $\mathrm{Pb}$ in plants reduced (Fig. 4A, B, C). Similarly, Jatav et al. (2016) showed that maximum and minimum uptake of $\mathrm{Cd}, \mathrm{Ni}$ and $\mathrm{Pb}$ were respectively obtained by only applying $30 \mathrm{t} / \mathrm{ha}$ of sewage sludge and $20 \mathrm{t} / \mathrm{ha}$ biochar plus $30 \mathrm{t} / \mathrm{ha}$ of sewage sludge. Increasing the amount of applied biochar reduced in heavy metal uptake. Al-Wabel et al. (2015) showed that $5 \%$ biochar application reduced heavy metal $(\mathrm{Cu}, \mathrm{Zn}, \mathrm{Mn}$, and $\mathrm{Cd})$ in corn plants.

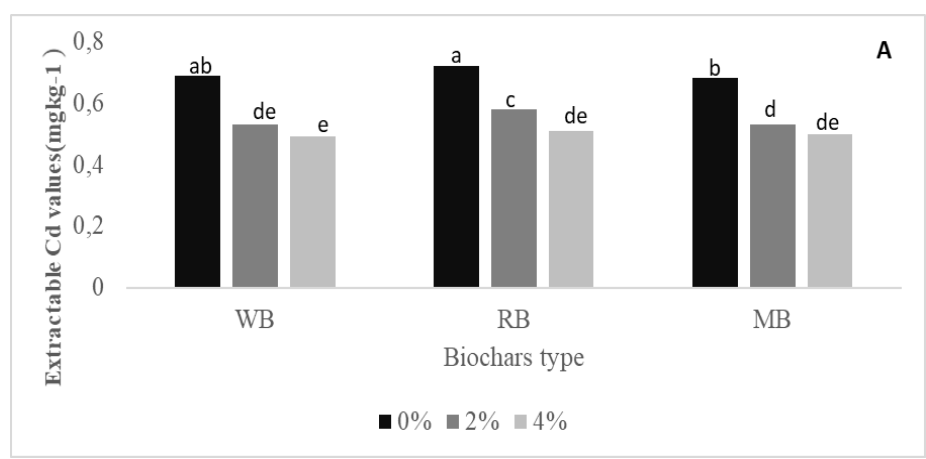




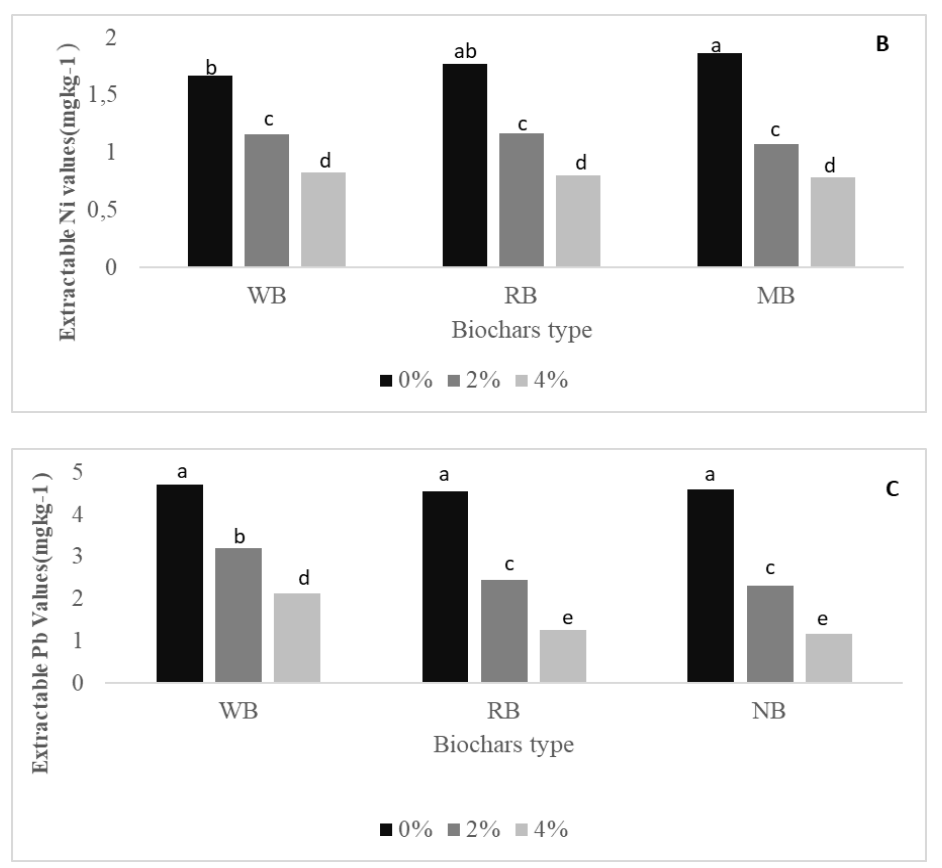

Figure 4. Effect of different rates of biochar different rates on shoot extractable $\mathrm{Cd}(\mathrm{A}), \mathrm{Ni}(\mathrm{B})$ and $\mathrm{Pb}(\mathrm{C})$

Among higher plants, there are two groups of plants that can tolerate high concentrations of heavy metals: excluder plants and accumulator plants. The former is able to inhibit heavy metal transport into the plants whereas the later uptake heavy metals and accumulate them in different parts for example, roots or shoots (Lu et al., 2015). In this study, translocation factor (TF) was determined by using the ratio of heavy metal concentration in shoots to roots $\left(\mathrm{TF}=\mathrm{C}_{\text {shoot }} / \mathrm{C}_{\text {root }}\right)(\mathrm{Bu}-$ Olayan and Thomas, 2009). Statistical analyses showed that $\mathrm{TF}$ value was affected by biochar type and amount (Table 3 and 7$)$. The minimum $\mathrm{TF}_{\mathrm{Cd}}(0.23)$ was related to $\mathrm{WB}_{2} \%$ whereas the minimum $\mathrm{TF}_{\mathrm{Ni}}(0.28)$ and $\mathrm{TF}_{\mathrm{Pb}}(0.33)$ were related to $\mathrm{MB}_{2 \%}$ and $\mathrm{MB}_{4 \%}$ respectively. Accumulator plants can be identified by $\mathrm{TF}>1$ whereas excluders can be recognized by $\mathrm{TF}<1$ (Shumaker and Begonia, 2005). The results demonstrated that $\mathrm{TF}$ values for $\mathrm{Cd}, \mathrm{Ni}$ and $\mathrm{Pb}$ were less than 1 .

Table 7. Effect of different rates of biochars on shoot, root, soil properties, plant indices and translocation factor (values are mean of three replications)

\begin{tabular}{|c|c|c|c|c|c|c|c|c|c|c|c|c|c|c|c|c|c|c|c|c|}
\hline \multirow{3}{*}{ Biochar } & \multirow{3}{*}{ Rate } & \multicolumn{3}{|c|}{ Shoot } & \multicolumn{3}{|c|}{ Root } & \multicolumn{6}{|c|}{ Soil } & \multicolumn{4}{|c|}{ Plant } & \multicolumn{3}{|c|}{ TF value } \\
\hline & & $\mathrm{Cd}$ & $\mathrm{Ni}$ & $\mathbf{P b}$ & $\mathrm{Cd}$ & $\mathrm{Ni}$ & $\mathbf{P b}$ & $\mathrm{Cd}$ & $\mathrm{Ni}$ & $\mathbf{P b}$ & pH & EC & OC & LA & Shoot & Root & R:S & $\mathbf{T F}_{\mathrm{Cd}}$ & $\mathbf{T F}_{\mathrm{Ni}}$ & $\mathbf{T F}_{\mathrm{Pb}}$ \\
\hline & & \multicolumn{9}{|c|}{$\mathrm{mg} \mathrm{kg}^{-1}$} & & $d S / m$ & $\%$ & $\mathrm{~cm}^{2}$ & \multicolumn{2}{|c|}{ gr } & & & & \\
\hline \multirow{3}{*}{ WB } & $\mathrm{R}_{0}$ & $0.69^{\mathrm{ab}}$ & $1.67^{b}$ & $4.73^{\mathrm{a}}$ & $2.45^{\mathrm{b}}$ & $4.71^{\mathrm{a}}$ & $8.48^{\mathrm{a}}$ & $0.50^{\mathrm{b}}$ & $3.38^{\mathrm{b}}$ & $2.78^{\mathrm{a}}$ & $7.47^{d}$ & $2.75^{\text {cd }}$ & $2.10^{\mathrm{c}}$ & $326.7^{\mathrm{d}}$ & $7.35^{\mathrm{b}}$ & $1.82^{\mathrm{c}}$ & $4.03^{\mathrm{b}}$ & $0.28^{\mathrm{a}}$ & $0.35^{\mathrm{bc}}$ & $0.55^{\mathrm{a}}$ \\
\hline & $\mathrm{R}_{2 \%}$ & $0.53^{\mathrm{de}}$ & $1.16^{\mathrm{c}}$ & $3.21^{\mathrm{b}}$ & $2.26^{\mathrm{c}}$ & $3.63^{\mathrm{b}}$ & $6.34^{\mathrm{b}}$ & $0.4^{\mathrm{c}}$ & $2.51^{\mathrm{e}}$ & $2.39^{\mathrm{bc}}$ & $7.59^{\mathrm{bc}}$ & $3.02^{\mathrm{bc}}$ & $3.23^{\mathrm{d}}$ & $294.8^{\mathrm{ef}}$ & $7.07^{\mathrm{c}}$ & $1.71^{\mathrm{e}}$ & $4.13^{\mathrm{a}}$ & $0.23^{\mathrm{c}}$ & $0.32^{\mathrm{b}}$ & $0.50^{\mathrm{b}}$ \\
\hline & $\mathrm{R}_{4 \%}$ & $0.49^{\mathrm{e}}$ & $0.83^{\mathrm{d}}$ & $2.14^{\mathrm{d}}$ & $2.08^{\mathrm{d}}$ & $2.38^{\mathrm{c}}$ & $3.91^{\mathrm{cd}}$ & $0.33^{\mathrm{e}}$ & $1.44^{\mathrm{g}}$ & $1.98^{\mathrm{d}}$ & $7.71^{\mathrm{a}}$ & $3.42^{\mathrm{a}}$ & $4.19^{\mathrm{b}}$ & $262.7^{\mathrm{g}}$ & $6.73^{\mathrm{d}}$ & $1.61^{\mathrm{f}}$ & $4.19^{\mathrm{a}}$ & $0.24^{\mathrm{bc}}$ & $0.37^{\mathrm{ab}}$ & $0.55^{\mathrm{a}}$ \\
\hline \multirow{3}{*}{$\mathrm{RB}$} & $\mathrm{R}_{0}$ & $0.72^{\mathrm{a}}$ & $1.77^{\mathrm{ab}}$ & $4.54^{\mathrm{a}}$ & $2.60^{\mathrm{a}}$ & $4.64^{\mathrm{a}}$ & $8.56^{\mathrm{a}}$ & $0.50^{\mathrm{b}}$ & $3.60^{\mathrm{a}}$ & $2.69^{\mathrm{ab}}$ & $7.39^{\mathrm{e}}$ & $2.62^{\mathrm{d}}$ & $2.20^{\mathrm{c}}$ & $349.8^{\mathrm{b}}$ & $7.46^{\mathrm{ab}}$ & $1.90^{\mathrm{ab}}$ & $3.92^{\mathrm{de}}$ & $0.28^{\mathrm{a}}$ & $0.37^{\mathrm{ab}}$ & $0.54^{\mathrm{a}}$ \\
\hline & $\mathrm{R}_{2 \%}$ & $0.58^{c}$ & $1.18^{\mathrm{c}}$ & $2.44^{\mathrm{c}}$ & $2.10^{\mathrm{d}}$ & $3.69^{\mathrm{b}}$ & $6.52^{\mathrm{b}}$ & $0.44^{c}$ & $2.95^{\mathrm{c}}$ & $2.23^{\text {cd }}$ & $7.52^{\mathrm{cd}}$ & $2.86^{\mathrm{cd}}$ & $3.64^{\circ}$ & $329.9^{\mathrm{cd}}$ & $7.44^{\mathrm{ab}}$ & $1.88^{\mathrm{b}}$ & $3.97^{\mathrm{bcd}}$ & $0.28^{\mathrm{a}}$ & $0.32^{\mathrm{c}}$ & $0.38^{\mathrm{c}}$ \\
\hline & $\mathrm{R}_{4 \%}$ & $0.51^{\mathrm{de}}$ & $0.80^{\mathrm{d}}$ & $1.26^{\mathrm{e}}$ & $2.05^{\mathrm{d}}$ & $2.47^{\mathrm{c}}$ & $3.99^{\mathrm{c}}$ & $0.29^{\mathrm{f}}$ & $1.89^{\mathrm{f}}$ & $2.08^{\mathrm{d}}$ & $7.62^{\mathrm{b}}$ & $3.21^{\mathrm{ab}}$ & $4.96^{\mathrm{a}}$ & $288.2^{\mathrm{f}}$ & $7.13^{\mathrm{c}}$ & $1.78^{\mathrm{d}}$ & $4.02^{\mathrm{bc}}$ & $0.25^{\mathrm{b}}$ & $0.33^{\mathrm{c}}$ & $0.33^{\mathrm{e}}$ \\
\hline \multirow{3}{*}{ MB } & $\mathrm{R}_{0}$ & $0.68^{\mathrm{b}}$ & $1.86^{\mathrm{a}}$ & $4.57^{\mathrm{a}}$ & $2.38^{\mathrm{b}}$ & $4.71^{\mathrm{a}}$ & $8.59^{\mathrm{a}}$ & $0.55^{\mathrm{a}}$ & $3.54^{\mathrm{a}}$ & $2.65^{\mathrm{ab}}$ & $7.39^{\mathrm{c}}$ & $2.65^{\mathrm{d}}$ & $2.22^{\mathrm{e}}$ & $357.8^{\mathrm{a}}$ & $7.49^{\mathrm{a}}$ & $1.93^{\mathrm{a}}$ & $3.88^{\mathrm{e}}$ & $0.39^{\mathrm{a}}$ & $0.39^{\mathrm{a}}$ & $0.54^{\mathrm{a}}$ \\
\hline & $\mathrm{R}_{2 \%}$ & $0.53^{\mathrm{d}}$ & $1.07^{\mathrm{c}}$ & $2.31^{\mathrm{c}}$ & $1.96^{\mathrm{c}}$ & $3.76^{\mathrm{b}}$ & $6.67^{\mathrm{b}}$ & $0.36^{\mathrm{d}}$ & $2.63^{\mathrm{d}}$ & $2.19^{\text {cd }}$ & $7.56^{\mathrm{bc}}$ & $2.70^{\mathrm{cd}}$ & $3.70^{\mathrm{c}}$ & $337.2^{c}$ & $7.48^{\mathrm{ab}}$ & $1.89^{\mathrm{b}}$ & $3.94^{\text {cde }}$ & $0.28^{\mathrm{a}}$ & $0.28^{\mathrm{d}}$ & $0.36 \mathrm{~d}$ \\
\hline & $\mathrm{R}_{4 \%}$ & $0.50^{\mathrm{de}}$ & $0.78^{\mathrm{d}}$ & $1.17^{\mathrm{e}}$ & $1.76^{\mathrm{f}}$ & $2.57^{\mathrm{c}}$ & $3.36^{\mathrm{d}}$ & $0.29^{f}$ & $1.53^{\mathrm{g}}$ & $2.15^{\mathrm{cd}}$ & $7.62^{\mathrm{b}}$ & $2.75^{\mathrm{cd}}$ & $4.98^{\mathrm{a}}$ & $297.3^{\mathrm{e}}$ & $7.18^{\mathrm{c}}$ & $1.81^{\mathrm{c}}$ & $3.97^{\mathrm{bcd}}$ & $0.29^{\mathrm{a}}$ & $0.29^{\mathrm{d}}$ & $0.33^{\mathrm{de}}$ \\
\hline $\begin{array}{c}\text { LSD } \\
(0.01)\end{array}$ & & 0.035 & 0.098 & 0.138 & 0.098 & 0.240 & 0.285 & 0.036 & 0.196 & 0.219 & 0.069 & 0.346 & 0.219 & 16.82 & 0.208 & 0.03 & 0.170 & 0.069 & 0.020 & 0.033 \\
\hline
\end{tabular}

Different letters indicate significant differences between treatments $\mathrm{P}<0.05$ 


\section{Effect of biochar on leaf area, shoot and root biomass}

This study results indicated that the effects of biochar type were significant ( $\mathrm{P}<0.05)$ on leaf area, shoot and root biomass (Table 3). Comparison of means showed that $\mathrm{MB}_{700}$ caused the maximum leaf area $\left(330.8 \mathrm{~cm}^{2}\right)$, shoot $(7.37 \mathrm{~g})$, and root biomass $(1.93 \mathrm{~g})$, respectively. The minimum leaf area $\left(294.7 \mathrm{~cm}^{2}\right)$ and root biomass $(1.61 \mathrm{~g})$ were related to $\mathrm{WB}_{700}$. This study results showed that leaf area, shoot and root biomass significantly decreased with increasing biochar application (Table 7). In current research, produced biochars showed different properties which resulted in different effects on soil (Paneque et al., 2016) and thus may result in different responses from plants (da Silva et al., 2017). Results analysis (Table 6) showed that Na concentration in biochars was 4900-6800 mg kg-1. Increasing biochar dose can increase $\mathrm{Na}$ in soil. Rajkovich et al. (2011) reported that $\mathrm{Na}$ negatively (especially in low salty soil) affects maize growth, increases the soil osmotic potential and reduces the water uptake by plants. However, the liming effect of biochar is considered positive property for acidic soils but in soils with high $\mathrm{pH}$, liming effect can have undesirable effects (Alburquerque et al., 2014). As well as Paneque et al. (2016) reported that large specific surface area of some biochars with high CEC and water holding capacity may have increased the competition for water which cuts down the potentially positive effect of biochar amendment.

\section{Conclusion}

Application of biochar in a semi-arid environment with high alkaline soil, high lime and rather low organic matter resulted in reduction of $\mathrm{Cd}, \mathrm{Ni}$, and $\mathrm{Pb}$ in both soil and plants however high level application of biochar, increased the $\mathrm{pH}$ and $\mathrm{EC}$ of the soil and reduced plants growth indices like leaf area and shoot and root biomass. Effects of $\mathrm{MB}_{700}$ was less than effects of $\mathrm{WB}_{700}$ and $\mathrm{RB}_{700}$ on the mentioned growth indices. To reduce the translocation of heavy metals to plants and biochar effects on growth indices, application of $2 \%$ or less from $\mathrm{MB}_{700}$ is recommended. Production of biochar with less $\mathrm{EC}$ and $\mathrm{pH}$ and suitable application dose in lime soils of semi-arid regions may be beneficial but requires more studies.

\section{REFERENCES}

[1] Abdelhafez, A. A., Li, J., Abass, M. H. (2014): Feasibility of biochar manufactured from organic waste on stabilization of heavy metals in a metal smelter contaminated soil. Chemosphere 117: 66-71.

[2] Ahmad, M., Rajapaksha, A. U., Lim, J. E., Zhang, M., Bolan, N., Mohan, D., Vithanage, M., Lee, S. S., OK, Y. S. (2014): Biochar as a sorbent for contaminant management soil and water. - Italian Chemosphere 99: 19-33.

[3] Alburquerque, J. A., Calero, J. M., Barron, V., Torrent, J., Del Campillo, M. C., Gallardo, A., Villar, R. (2014): Effect of biochars produced from different feedstocks on soil properties and sunflower growth. - Journal of Plant Nutrition and Soil Science 177(1): pp16-25.

[4] ASTM International (2009): D5142 Standard Test Method for Proximate Analysis of the analysis Sample of Coal and Koke Instrumental Procedures. - American Society for Testing and Material (ASTM) International, USA. 
[5] Brunauer, S., Emmett, P. H., Teller, E. (1938): Adsorption of gases in multimolecular layers. - Journal of American Chemical Society 60(2): 309-319.

[6] Bu-Olayan, A. H., Thomas, B. V. (2009): Translocation of trace metals in desert plants of Kuwait governorates. - Research Journal of Environmental Sciences 3(5): 581-587.

[7] Cao, X., Ma, L., Gao, B., Haris, W. (2009): Dairy-manure derived biochar effectively sorbs lead and atrazine. - Environ. Sci. Technol. 43: 3285-3291.

[8] da Silva, I. C. B., Basilo, J. J. N., Fernandes, L. A., Colen, F., Sampaio, R. A., Frazáo, L. A. (2017): Biochip from different residues on soil properties and common bean production. - Sci. Agric. 74(5): 378-382.

[9] Dume, B., Mosisa, T., Nebiyu, A. (2016): Effect of biochar on soil properties and lead $(\mathrm{Pb})$ availability in military camp in south west Ethiopia. - Afri. J. Envi. Sci. Tech. 10(3): 77-85.

[10] Elzobair, K. (2013): Biochar effects on soil microbial communities and resistance of enzymes to stress. - Thesis, Department of Soil and Crop Science, Colorado State University.

[11] Hejazizadeh, A., Gholamizadeh Ahangar, A., Ghorbani, M. (2016): Effect of biochip on lead and cadmium from applied paper factory sewage sludge by sunflower (heliantus annus L.). - Water and Soil Science University of Tabriz 26(1/2): 259-271.

[12] Ingole, S. P., Tale, S. S. (2016): Review on toxicity assessment for carcinogenic soil contaminants. - The Pharmaceutical and Chemical Journal 3(2): 139-144.

[13] Kacálková, L., Tlustoš, P., Sźakpvá, J. (2014): Chromium, nickel and lead accumulation in mize, sunflower, willow and poplar. - Pol. J. Environ. Stud. 23(3): 753-761.

[14] Karami, N., Clemente, R., Moreno-Jimenez, E., Lepp, N. W., Beesley, L. (2011): Efficiency of green waste compost and biochar soil amendments for reducing lead and copper mobility and uptake to rygrass. - Journal of Hazardous Materials 191: 41-48.

[15] Komkiene, J., Baltrenaite, E. (2016): Biochar as adsorbent for removal heavy metal ions cadmium (II), copper (II), lead (II), zinc (II) from aqueous phase. - Int. J. Environ. Sci. Technol. 13: 471-482.

[16] Kopittke, P. M., Asher, C. J., Menzies, N. W. (2008): Prediction of Pb speciation in concentrated and dilute nutrient solutions. - Environ. Pollut. 153: 548-554.

[17] Lehmann, J. (2007): A handful of carbon. - Nature 447(May): 10-11.

[18] Lindsay, W. L., Norvell, W. A. (1978): Development of DTPA soil test for zinc, iron, manganese and copper. - Soil Science Society of America Journal 42(3): 421-428.

[19] Lu, Y., Yao, H., Shan, D., Jiang, Y., Zhang, S., Yang, J. (2015): Heavy metal residues in soil and accumulation in maize at long- term wastewater irrigation area in Tongliao, China. - Hindawi Journal of Chemistry. http://dx.doi.org/10.1155/2015/628280.

[20] Melo, L. C. A., Coscione, A. R., Albreu, C. A., Puga, A. P., Camargo, O. A. (2013): Influence of pyrolysis temperature on Cadmium and zinc sorption capacity of sugar cane straw- derived biochip. - Bio Resources 8(4): 4992-5004.

[21] Mousavi, H. Z., Hosseinifar, A., Jahed, V. (2011): Removal of $\mathrm{Cu}^{\mathrm{II}}$ from wastewater by waste tire rubber ash. - J. Ser. Chem. Soc. 75: 845-753.

[22] Novak, J. M., Lima, I., Xing, B., Gaskin, J. W., Steiner, C., Das, K. C., Ahmendna, M., Rehra, D., Watts, D. W., Busscher, W. J., Schomberg, H. (2009): Characterization of designer biochar produced at different temperature and their effects on a loamy sand. Annals of Environmental Science 2: 195-206.

[23] Nguyen, B. T., Lehmann, J. (2009): Black carbon decomposition under varying water regimes. - Org. Geochem. 40: 846-835.

[24] Paneque, M., De la Rosa, J. M., Franco-Navarro, J. D., Colmenero-Flores, J. M., Knicher, H. (2016): Effect of biochar amendment on morphology, productivity and water relations of sunflower plants under non- irrigation conditions. - Catena 147:280-287.

[25] Park, J. H., Choppala, G. K., Bolan, N. S., Chaung, J. W., Chuasavathi, T. (2011): Biochar reduces the bioavailability and phytotoxicity of heavy metals. - Plant Soil 348: 439-451. 
[26] Paz-Ferreiro, J., Lu, H., Fu, S., Mendez, A., Gasco, G. (2014): Phytoremedation and biochar to remediate heavy metal polluted soils: a review. - Solid Earth 5: 65-75.

[27] Qayyum, M. F., Abid, M., Danish, S., Saeed, M. K., Ali, M. A. (2015): Effect of various biochars on seed germination and carbon mineralization in an alkaline soil. - Pak. J. Agri. Sci. 51(4): 977-982.

[28] Rajkovich, S., Enders, A., Hanley, K., Hyland, C., Zimmerman, A. R. (2011): Corn growth and nitrogen nutrition after additions of biochars with varying properties to temperate soil. - Biol. Ferti. Soils. 48: 271-284.

[29] Rajkovich, S., Enders, A., Hanley, K., Haylands, C., Zimmerman, A. R., Lehmann, J. (2012): Corn Growth and nitrogen nutrition after additions of biochar with varying properties to temperate soil. - - Biology and Fertility of Soils 47(3): 271-84.

[30] Sadaka, S., Sharara, M. A., Ashworth, A., Keyser, P., Allen, F., Wright, A. (2014): Characterization of biochar from switchgrass carbonization. - Energies 7: 548-567.

[31] Schmidt, M. W., Noack, A. G. (2000): Black carbon in soil and sediments: analysis, distribution, implications and current challenges. - Glob Biogeochem Cycle 14(3): 777793.

[32] Shumaker, K. L., Begonia, G. (2005): Heavy metal uptake, translocation and bioaccumulation studies of (Triticum aestivum) cultivated in contaminated dredged materials. - Int. J. Environ. Res. Public Health. 2(2): 293-298.

[33] Song, W., Guo, M. (2012): Quality variations of poultry litter biochar generated at different pyrolysis temperature. - J. Anal. Appl. Pyrolysis. 94: 138-145.

[34] Uchimiya, M., Lima, I. M., Classon, K. T., Chang, S., Wartelle, L. H., Rodgres, J. E. (2010): Immobilization of heavy metal ions $\left(\mathrm{Cu}^{\mathrm{II}}, \mathrm{Cd}^{\mathrm{II}}, \mathrm{Ni}^{\mathrm{II}}\right.$ and $\left.\mathrm{Pb}^{\mathrm{II}}\right)$ by broiler litterderived biochars in water and soils. - J. Agric. Food Chem. 58: 5538-5544.

[35] Uchimiya, M., Chang, S., Klasson, K. T. (2011): Screening biochars for heavy metal retention in soil: Role of Oxygen functional groups. - Journal of Hazardous Materials 190: 432-441.

[36] Wang, S., Gao, B., Zimmerman, A. R., Li, Y., Ma, L., Harris, W. G., Migliaccio, K. W. (2015): Physiochemical and adsorptive properties of biochars derived from woody and herbaceous biomass. - Chemosphere 134: 257-262.

[37] Wolf, B. (1982): The comprehensive system of lead analysis and its use for diagnosing crop nutrient status. - Comm Soil Sci. Plant Anal. 13: 1035-1059.

[38] Wu, W., Yang, M., Feng, Q., McGrouther, K., Wang, H., Lu, H., Chen, Y. (2012): Chemical characterization of rice straw-derived biochar for soil amendment. - Biomass Bioenerg. 47: 268-276.

[39] Yang, X., Liu, J., Mc Grother, K., Huang, H., Lu, K., Guo, X., He, L., Lin, X., Che, L., Ye, Z., Wang, H. (2015): Effect of biochar on extractability of heavy metals $(\mathrm{Cd}, \mathrm{Cu}, \mathrm{Pb}$ and $\mathrm{Zn}$ ) and enzyme activity in soil. - Environ Sci. Pollut Res. 23: 974-984.

[40] Yao, Y., Gao, B., Zhang, M., Inyang, M., Zimmerman, A. R. (2012): Effect of biochar amendment on sorption and leaching of nitrate ammonium and phosphate in a sandy soil. - Chemosphere 89: 1467-1471.

[41] Zhang, J., Lu, F., Zhang, H., Shao, L., Chen, D., He, P. (2015): Multiscale visualization of the structural and characteristic changes of sewage sludge biochar oriented towards potential agronomic and environmental implication. - Scientific Report 5: 9406.

[42] Zhao, S. X., Ta, N., Wang, X. D. (2017): Effect of temperature on the structural and physiochemical properties of biochar with apple tree branches as feedstock material. Energies 10: 1293. DOI: 10.3390/en10091293.

[43] Zheng, R., Chen, Z., Cai, C., Wang, X., Huang, Y., Xiao, B., Sun, G. (2013): Effect of biochars from rice husk, bran and straw on heavy metal uptake by post-grown wheat seedling in a historically contaminated soil. - Biores. 8: 5965-5982. 